JOEAI (Journal of Education and Instruction)

Volume 2, Nomor 2, Desember 2019

e-ISSN : 2614-8617

p-ISSN : 2620-7346

DOI: https://doi.org/10.31539/joeai.v2i2.723

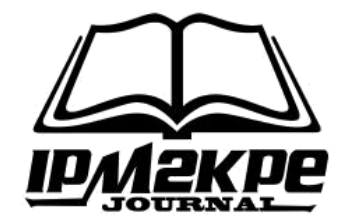

\title{
PENGARUH METODE PARTISIPATORI TERHADAP KEMAMPUAN MENULIS TEKS DESKRIPSI
}

\author{
Gina Julia Berbudi ${ }^{1}$, Nanang Chaerul Anwar ${ }^{2}$, David Setiadi ${ }^{3}$ \\ Universitas Muhammadiyah Sukabumi ${ }^{1,2,3}$ \\ Ginajuliaberbudi022@ummi.ac.id ${ }^{1}$
}

\begin{abstract}
ABSTRAK
Penelitian ini bertujuan untuk menguji pengaruh metode partisipatori terhadap kemampuan menulis teks deskripsi siswa kelas VII SMP Negeri 1 Kota Sukabumi Tahun Pelajaran 2018/2019. Subjek utama dalam penelitian ini yaitu siswa kelas VII G yang berjumlah 36 siswa. Tujuan diadakannya penelitian ini yaitu untuk mengetahui kemampuan menulis teks deskripsi sebelum dan setelah menggunakan metode partisipatori, dan mengetahui pengaruh metode partisipatori terhadap kemampuan menulis teks deskripsi. Metode penelitian yang digunakan dalam penelitian ini yaitu metode kuantitatif dengan menggunakan desain penelitian one group pretest-posttest design. Hasil penelitian yang diperoleh ketika pretest nilai rata-rata siswa yaitu 40 sedangkan nilai rata-rata posttest 65.41. Hal tersebut mengalami peningkatan setelah peneliti menggunakan metode partiipatori. Hasil perhitungan masing-masing tes dilakukan dengan menggunakan uji-t siginifikasikan terhadap pretest dan posttest sehingga diperoleh hasil bahwa $\mathrm{t}_{\text {hitung }}(12.29)>\mathrm{t}_{\text {tabel. }}$. Hasil ini menunjukkan adanya perbedaan yang terjadi antara pretest dan posttest. Dapat disimpulkan bahwa metode pembelajaran partisipatori berpengaruh terhadap kemampuan menulis teks deskripsi siswa kelas VII SMP Negeri 1 Kota Sukabumi.
\end{abstract}

Kata Kunci: Menulis, Teks Deskripsi, Partisipatori.

\begin{abstract}
This study aims to examine the effect of participatory methods on the ability to write descriptive text for grade VII students of SMP Negeri 1 Sukabumi City in 2018/2019 Academic Year. The main subjects in this study were students of class VII $G$, amounting to 36 students. The purpose of this research is to know the ability to write description text before and after using participatory methods, and determine the effect of participatory methods on the ability to write descriptive text. The research method used in this study is a quantitative method using a one group pretest-posttest design research design. The results of the study were obtained when the pretest average value of students is 40 while the posttest average value of 65.41. This has increased after researchers used participatory methods. The results of the calculation of each test were carried out using the $t$ test and it was significant to pretest and posttest so that the results obtained were tcount (12.29)> ttable. These results indicate a difference that occurs between the pretest and posttest. It can be concluded that participatory learning methods affect the ability to write description texts for grade VII students of SMP Negeri 1 Sukabumi.
\end{abstract}

Keywords: Writing, Description Text, Participatory 


\section{PENDAHULUAN}

Proses pembelajaran menulis mengkaji beberapa keterampilan pembelajaran (berbicara, menyimak, dan membaca), melalui keterampilan menulis, siswa diharapkan mampu mengembangkan kreativitas, intuisi, imajinasi dan daya nalar. Prinsip penting dalam pembelajaran menulis adalah materi yang disajikan kepada siswa harus setingkat/sesuai dengan kemampuan siswa pada suatu tingkatan atau tahapan pembelajaran yang telah ditentukan. Pembelajaran menulis erat kaitannya dengan komunikasi tulis karena sifat penggunaannya yang saling berkaitan dalam aspek ilmu bahasa (Nurgiyantoro \& Burhan, 2001).

Menurut Tarigan (2008) ada empat jenis aspek proses komunikasi yaitu: Komunikator, Pesan, Saluran dan Audinece (penonton dan pendengar) ke empat jenis aspek proses komunikasi itu sangat penting dalam melakukan kegiatan menulis. Kemampuan menulis akan mudah dikuasai apabila penulis mampu menerjemahkan ke empat aspek proses komunikasi tersebut. Pembelajaran menulis memiliki berbagai macam bentuk, salah satunya adalah keterampilan menulis teks deskripsi. dalam penelitian yang akan diteliti, peneliti mengarahkan siswa pada bagian menulis teks deskripsi siswa kelas VII khususnya di SMPN 1 Kota Sukabumi. Berdasarkan Pengamatan dan observasi yang dilakukan oleh peneliti di SMPN 1 Kota Sukabumi, kemampuan menulis siswa khususnya teks deskripsi masih terbilang rendah, hal ini terlihat dari hasil wawancara dengan guru mata pelajaran bahasa Indonesia dan pengamatan langsung yang dilakukan oleh peneliti. Pada praktiknya siswa merasa kesulitan dalam pengembangan ide, gagasan dalam menulis deskripsi dan siswa sering mengsalahartikan antara menulis deskripsi dan menulis narasi, shingga mengakibatkan kesalahpahman yang dialami oleh siswa (Andayani, 2015).

Berdasarkan permasalahan di atas, dibutuhkan sebuah metode dalam proses pembelajaran yang sesuai untuk mencapai tujuan tertentu. Hal ini bertujuan untuk menunjang keberhasilan pembelajaran dan tercapai dengan baik. Metode yang akan digunakan dalam penelitian ini adalah metode partisipatori karena metode tersebut menempatkan siswa sebagai subjek pembelajaran dan menekankan keterlibatan siswa secara penuh dan terjadi interaksi positif antara siswa dengan guru. Metode Partisipatori merupakan metode pembelajaran yang lebih menekankan keterlibatan siswa secara penuh. Siswa merupakan bentuk keberhasilan dari proses pembelajaran. Peserta didik ditempatkan sebagai subjek belajar (Ardiansyah, M., 2016). Tujuan penelitian ini adalah untuk mengetahui pengaruh metode partisipatori terhadap kemampuan menulis deskriptif siswa SMPN 1 Kota Sukabumi.

\section{METODE PENELITIAN}

Penelitian yang akan dilakukan oleh peneliti menggunakan metode kuantitatif dengan cara eksperimen. Metode penelitian eksperimen merupakan 
metode penelitian yang digunakan untuk mencari pengaruh terhadap suatu tindakan yang diberikan. Sebagaimana dikemukakan oleh Sanjaya (2014) metode eksperimen merupakan metode penelitian yang digunakan untuk mengetahui pengaruh dari suatu tindakan atau perlakuan tertentu yang sengaja dilakukan terhadap suatu kondisi tertentu. Perlakuan (treatment) yang dilakukan oleh penelitian ini adalah penerapan metode partisipatori terhadap kemampuan menulis teks deskripsi. Desain penenelitian yang digunakan oleh peneliti yaitu menggunakan desain penelitian One Group Pretes-Posttest Design. Rancangan tersebut terdapat pretest sebelum diberi perlakuan dengan demikian perlakuan dapat diketahui dengan akurat karena dapat membandingkan keadaan sebelum diberi perlakuan dan sesudah diberikan perlakuan. Pada pengumpulan data yang akan dilakukan dua kali untuk dijadikan bahan penelitian yaitu sebelum eksperimen $\left(\mathrm{O}_{1}\right)$ disebut prates dan observasi setelah eksperimen $\left(\mathrm{O}_{2}\right)$ disebut Pascates. Desain ini dapat digambarkan seperti berikut.

\section{Tabel 1}

Desain Penelitian

\begin{tabular}{ccc}
\hline $\mathrm{O}_{1}$ & $\mathrm{X}$ & $\mathrm{O}_{2}$ \\
\hline Pretest & Treatment & Postest
\end{tabular}

(Sugiyono, 2015:111)

Desain penelitian ini, peneliti terlebih dahulu memberikan tes awal atau (pretest) untuk mengetahui kemampuan siswa dalam menulis teks deskripsi sebelum menggunakan metode partisipatori kemudian test akhir atau posttest untuk mengetahui kemampuan siswa dalam menulis teks deskripsi sesudah menggunakan metode partisipatori.

Adapun cara pengambilan sebuah data yaitu dengan teknik pengambilan sampel yang dilakukan oleh peneliti menggunakan sample random sampling. Pada teknik sample random sampling pengambilan anggota sampel dan populasi dilakukan secara acak tanpa memperhatikan strata yang ada dalam populasi, setiap individu memiliki kesempatan atau peluang yang sama untuk dijadikan subjek penelitian. Setelah dilakukan teknik pengambilan sample random muncullah kelas VII G yang akan dijadikan sampel. Berikut data sampel siswa kelas VII G SMPN 1 Kota Sukabumi.

\section{HASIL DAN PEMBAHASAN}

Penelitian ini di laksanakan di SMP Negeri 1 Kota Sukabumi adalah salah satu sekolah menengah pertama yang terletak di jalan Ir.H.Djuanda Nomor 6 Kota Sukabumi, kecamatan Cikole, kota Sukabumi, provinsi Jawa Barat. No tlp (0266) 221672242968 Fax (0266) 2422968. SMP Negei 1 Kota Sukabumi telah menyiapkan berbagai ruangan yang mendukung proses pembelajaran seperti laboratorium IPA, ruang multimedia, perpustakaan, ruang seni dan lainnya dengan sangat baik. SMP Negeri 1 Kota Sukabumi memiliki siswa sebanyak 1308 orang. Setelah dilakukan teknik pengambilan sample random muncullah kelas VII G 
yang akan dijadikan sampel kemudian peneliti melakukan kegiatan pretest treatment dan posttest dengan tujuan untuk mengetahui bagaiaman kemampuan siswa sebelum dan sesudah menggunakan metode partisipatori. berikut data skor pretest.

\section{Kemampuan Menulis Teks Deskripsi Siswa Kelas VII SMP Negeri 1 Kota Sukabumi Sebelum Menggunakan Metode Partisipatori.}

Penilaian hasil Pretest berdasarkan rumus

$\mathrm{NP}=\frac{\mathrm{R}}{\mathrm{SM}} \times 100$

Keterangan:

NP : Nilai persen yang dicari atau diterapkan

$\mathrm{R} \quad$ : Skor mentah yang diperoleh siswa

SM : Skor maksimal ideal dari tes yang bersangkutan

100 : Nilai tetap

Berdasarkan hasil kemampuan siswa dalam menulis teks deskripsi pada kegiatan awal maka dapat diketahui siswa yang mendapatkan nilai tertinggi sebanyak satu orang dengan jumlah nilai 65, siswa yang mendapat nilai 60 sebanyak tiga orang, serta siswa yang mendapat nilai 55 sebanyak dua orang, adapun siswa yang mendapat nilai 45 sebanyak sepuluh orang, nilai 40 sebanyak empat siswa, yang mendapatkan nilai 35 sebanyak dua orang, kemudian yang mendapat nilai 30 sebanyak dua orang dan yang mendapat nilai 25 sebanyak sembilan orang, selanjutnya yang mendapat nilai 20 satu orang. Jumlah nilai ratarata siswa menulis teks deskripsi sebesar 40.

\section{Kemampuan Menulis Teks Deskripsi Siswa Kelas VII SMP Negeri 1 Kota Sukabumi Setelah Menggunakan Metode Partisipatori.}

Data hasil tes akhir diperoleh ketika melakukan tes menulis teks deskripsi kepada siswa setelah diberikan perlakuan dengan menggunakan metode partisipatori maka dapat diperoleh nilai sebagai berikut. Tujuannya untuk mengetahui kemampuan siswa dalam menulis teks deskripsi setelah diberikan perlakuan (treatment) Berdasarkan perolehan nilai yang diperoleh siswa SMPN 1 Kota Sukabumi ketika tes akhir mengalami peningkatan, nilai tertinggi yang diperoleh yaitu 80 sebanyak satu orang, siswa yang mendapat nilai 75 sebanyak tujuh orang, yang mendapat nilai 70 sebanyak dua orang, dan yang mendapat nilai 65 sebanyak dua belas orang, yang mendapat 65 sebanyak dua belas orang, yang mendapat 60 sebanyak dua belas orang, yang mendapat nilai 55 sebanyak dua orang.

\section{Pengaruh Metode Partisipatori Terhadap Kemampuan Menulis Teks Deskripsi Siswa Kelas VII SMP Negeri 1 Kota Sukabumi}

Pengaruh metode partisipatori dapat diketahui dari hasil distribusi nilai pretest dan posttest. Peneliti melakukan uji perbedaan untuk menentukan nilai 
selisih gaind $(d)$. Adapun selisih kemampuan menulis teks deskripsi dengan menggunakan metode partisipatori siswa kelas VII G SMP Negeri 1 Kota Sukabumi. untuk mencari nilai rata-rata dengan cara nilai posttest dikurangi nilai pretest kemudian hasilnya di jumlahkan subjek pertama dan subjek akhir dengan hasil yaitu 885 denga rata-rata 24.58 dengan demikian nilai siswa saat melakukan kegiatan posttest mengalami peningkatan di bandingkan dengan pretest. penelitian nilai pretest siswa memeperoleh nilai rata-rata 40 dan nilai posttest dengan ratarata 65.41. Berdasarkan data yang sudah dihasilkan dapat disimpulkan bahwa kemampuan menulis teks deskripsi siswa dengan menggunakan metode partisipatori mengalami peningkatan.

Berdasarkan nilai tes awal menunjukkan bahwa nilai yang diperoleh siswa saat melakukan tes awal hampir seluruh siswa mendapatkan nilai rendah dan nilai yang diberikan kepada siswa ketika menulis teks deskripsi dilihat dari judul, identifikasi, deskripsi, penutup, penggunaan bahasa. Kemampun menulis teks deskripsi siswa pada kegiatan pretetst masih rendah dilihat dari skor rata-rata sebesar 40. Artinya, siswa belum memenuhi kriteria penilaian yang sudah ditentukan. Menurut pengamatan peneliti, anak lebih kaku dalam mengungkapkan pendapatnya, selain itu aspek pemahaman tentang materi yang diberikan juga ikut berpengaruh terhadap rendahnya kemampuan menulis deskripsi ini.

Pada kegiatan pembelajaran menulis teks deskripsi, kemampuan siswa dalam menulis teks deskripsi meningkat atau mengalami perubahan. Hal ini dilihat dari nilai rata-rata siswa setelah menggunakan metode partisipatori sebesar 65.41. Penggunaan metode partisipatori berpengaruh terhadap kemampuan menulis teks deskripsi siswa kelas VII G SMP Negeri 1 Kota Sukabumi. Hasil tersebut dapat dilihat dari hasil data pretest dan posttest yang mengalami peningkatan. Dengan memperoleh gain sebesar 885 dengan nilai rata-rata 24.58.

Dengan metode partisipatori peserta didik akan lebih mudah mengembangkan ide, gagasan dan pikiran yang akan di tuangkan dalam deskripsi, metode partisipatori mengajak anak untuk lebih berpartisipasi dalam setiap kegiatan pembelajaran yang ada.

\section{SIMPULAN}

Berdasarkan hasil pengolahan data yang dilakukan diketahui harga $t_{\text {hitung }}$ (12.29) kemudian $t_{\text {tabel }}$ (2.042) dengan taraf siginfikan 0,05 bahwa hasil pretest dan posttest berbeda yaitu mengalami peningkatan. Dengan demikian metode partisipatori berpengaruh terhadap kemampuan menulis teks deskripsi siswa kelas VII SMP Negeri 1 Kota Sukabumi. 


\section{DAFTAR PUSTAKA}

Andayani. (2015). Problema dalam Metodologi Pembelajaran Bahasa Indonesia. Jakarta: Deepublish

Ardiansyah, M., (2016). Pengaruh Metode Partisipatori Terhadap Hasil Belajar Matematika. Jurnal SAP, 1(61).

Nurgiyantoro \& Burhan. (2001). Penilaian dalam Pengajaran Bahasa dan Sastra Indonesia. Yogyakarta: BPFE

Sanjaya (2014). Strategi Pembelajaran Berorientasi Standar Proses Pendidikan. Jakarta: Kencana Prenada Media Group.

Tarigan, Hendry, G. (2008). Menulis Sebagai Keterampilan Berbahasa. Bandung: Angkasa Bandung. 